\title{
“SUDDENLY A BINGE DRINKING EPISODE HAS HAPPENED TO HIM": LOCUS OF CONTROL, NOTION OF RESPONSIBILITY, ALCOHOLISM AND SUICIDE IN THE TAZ REGION, YAMAL NENETS AUTONOMOUS OKRUG
}

\author{
KIRILL V. ISTOMIN \\ Senior Researcher \\ Institute of Language, Literature and History \\ Komi Science Center, Russian Academy of Sciences \\ Kommunisticheskaya 26, GSP-2, 167982 \\ Syktyvkar, Komi Republic, Russia \\ e-mail: kistomin@naver.com
}

\begin{abstract}
Although the notion of responsibility is often invoked by mass-media reports, activists and lay people when discussing alcoholism and suicides, anthropological discussions of this topic seem to deliberately avoid the notion. Based on the example of the Taz Nenets of western Sibera, this paper* explores how cross-cultural differences in the notion of responsibility, if approached in a non-moralising way, can enrich our understanding of several aspects of the drinking and suicidal behaviours of native northerners. The Nenets seem to believe that both positive and negative events in their lives happen more due to chance or for highly localised reasons that they do not control rather than being caused by their own informed and wilful actions (external locus of control). Particularly, acts of suicide and binge drinking episodes just happen to people and, therefore, people cannot be held responsible for them. This attitude can be a compensatory mechanism for the flat attribution style observed among Nenets in previous studies. It should be taken into account in programs of suicide prevention and the treatment of alcoholism.
\end{abstract}

KEYWORDS: alcoholism • suicide $\bullet$ locus of control $\bullet$ attribution style $\bullet$ Siberia $\bullet$ Nenets $\bullet$ responsibility taking

\section{N T RODUCTION}

Alcoholism and suicide represent enduring problems among the indigenous peoples of circumpolar regions (Arctic Human Development Report 2004). In the public discourse, particularly in the discourse prevalent in local and regional newspapers, TV and radio broadcasts, these problems are frequently discussed in moralistic terms and such topics as (moral) responsibility, irresponsible behaviour and free will (or lack of it) on the part of individuals are often invoked. This stands in a sharp contrast to academic lit-

* This research was supported by the ERA.Net RUS Plus Programme grant no. 189 (CORUNO). 
erature, including anthropological literature, which, once it gets to alcoholism and suicide, seems to carefully avoid the topic of individual responsibility, despite being quite willing to discuss it in other contexts. Indeed, this literature, which has proliferated significantly during last decades, points to a whole range of factors that can be blamed for the problems. These include political factors such as the sedentarisation policy (Pika 1987), collectivisation and the breakup of family households (Bogoyavlenskiy and Pika 1991; Klokov 1996); demographic factors such as urbanisation, the influx of newcomers (Kozlov et al. 2002), and the gender shift (Vitebsky and Wolfe 2001); economic factors such as poverty and economic insecurity (Pivneva 2005); social factors such as the lack of social mobility (Spillane and Smith 2007) and social disadaptation (Pivneva 2005); cultural factors such as a degradation of the traditional normative culture and of the traditional system of values (Abryutina 1999); even biomedical factors such as the alleged genetically based vulnerability of native northerners to alcoholism (Abryutina 1999; Pivneva 2005) to name just a few (and these are the factors discussed only in the context of Russian circumpolar regions). In these accounts, individuals are usually depicted as passive recipients of external influence, reacting to these factors by drinking or killing themselves. The question of their responsibility for their own behaviour is usually not discussed or even touched on.

This avoidance is completely understandable as far as discussion of responsibility is used (as this often happens in the popular mass-media discourse) as a context to make moral judgments about the behaviour of informants from the viewpoint of the author's moral principles or those of the 'universal society'. Indeed, such judgments would violate one of the fundamental principles of anthropological research, the principle of cultural relativity (and making moral judgments is in any case not the business of science). However, the notion of responsibility can be discussed in a number of other contexts even when the focus is on topics as sensitive and prone to moral judgement as alcoholism and suicide. Furthermore, at a certain level of research, such a discussion becomes absolutely necessary. Indeed, native northerners are not marionettes whose behaviour is directly and completely determined by political, demographic, social or other forces, despite the fact that some of the studies mentioned above can leave such an impression. Their behaviour, including drinking and suicidal behaviour, is determined primarily by their beliefs about what is right and what is wrong as well as about what they can do and what they should do. Political, social, demographic and, probably, even biomedical forces can influence their behaviour only by altering these beliefs. Therefore, any account that relates drinking and suicide among native northerners to any set of external factors should, at some point, provide a discussion of how these factors can cause specific behavioural patterns by influencing the notion of responsibility. Furthermore, an arguably better approach would be to start by describing the notion of responsibility among members of a particular group and only then speculate about how it can be related to drinking and suicidal behaviour on one hand and external forces on the other. Unfortunately few studies have utilised this approach so far.

This paper aims to explore this approach in a study of alcoholism and suicide among the Nenets of northwestern Siberia. As everywhere in the circumpolar region, the number of suicides per 100,000 inhabitants in this region is much higher among Nenets in comparison to non-aboriginal newcomers (Arctic Human Development Report 2004). Among Nenets, this number is very close to the mean for native northerners in Russia 
(101 per 100,000; Bogoyavlenskiy 2008), while among the non-aborigines it is in fact slightly lower than the mean for Russia in general (19 per 100,000, state statistical committee). Obtaining reliable data on alcoholism is more difficult, but there can be little doubt that the rate among native northerners is high (Pivneva 2005). Research presented in this paper represents a continuation of the previously published study by the author (Istomin 2012) drawing on psychological theories and methods. In contrast to the previous study, however, the data and results presented and discussed in this paper deal more directly with the notion of responsibility and its implication in drinking and suicidal behaviour.

The empirical data for this paper has been collected over the course of an extensive fieldwork period performed by the author in Tazovsky district, Yamal-Nenets Autonomous Okrug (Area), Russia. Geographically, this region includes the Gydan peninsula and the lower part of the River Taz. The fieldwork period included six visits to the area between 2005 and 2012. During these visits, which lasted two to four months each, the author migrated over the southern part of the district with nomadic reindeer herders (mainly members of the Tazovsky herding enterprise) and lived with semi-nomadic Nenets fishermen in the river Taz delta. In 2010, the author performed a comparative quantitative study of the so-called attribution style. The samples compared consisted of Nenets children from the Tazovsky boarding school for children of reindeer herders on the one hand, and of non-aboriginal children attending Tazovsky secondary school on the other. The current article draws on this study as well as on qualitative fieldwork data.

The paper consists of three parts. The first part discusses the concept of responsibility as well as theories that can account for differences in it between individuals and groups. The second part presents and discusses field material on the topic collected among Taz Nenets. The final part of the article explores some theoretical implications of this material.

\section{RESPONSIBILITY: A THEORETICAL ACCOUNT}

As was stated by Aristotle, responsibility should be understood as the ability to be blamed or prized (see Brown 2009). In other words, someone can be named responsible for his or her actions, including mental actions, if it is appropriate to respond to these actions with blame or praise. Aristotle continues by stating two conditions that make such responses appropriate. First is the so-called control condition: in order for an agent to be blamed or praised for his or her actions, these actions must have their origin in this agent and the agent should be able to control them. Second is the condition of awareness: it must be possible to expect the agent to be aware of the consequences of his or her actions that lead to blame or praise before the action itself is performed. This shows that only some agents can have responsibility and even these agents can be held responsible for only some of their actions (Eshleman 2014). The Aristotelian definition of responsibility and the conditions for being responsible have been accepted by most subsequent philosophers. Indeed, a heated debate has been going on about what agents' actions (if any) satisfy the control condition and what grounds (if any) are sufficient to expect an agent to satisfy the awareness condition (Woolfolk et al. 2008). However, the conditions themselves are not denied and those who argue that one or the other of them cannot be 
satisfied usually conclude that people simply cannot be properly held responsible for their actions (Eshleman 2014).

It seems that the reason the Aristotelian account of responsibility is widely accepted by both scholars and lay people is that the philosopher has managed to describe a true cultural and psychological universal (Nichols and Knobe 2007). Indeed, there seems to be no culture in the world whose members would not be blamed by their fellows for some actions and praised for others. The phenomena of blame and praise make up the foundation of the social order everywhere. At the same time, in all cultures people would be blamed or praised only for those actions that they performed while able to refrain. This ability to refrain can be just an illusion as fatalists or adherents of modern neuroethics would argue, but still this illusion should be there, otherwise there is indeed nothing the actor could be praised or blamed for (ibid.). Similarly, everywhere in the world people are expected to foresee the direct consequences of their actions and are blamed if they fail to do something and instead perform an action despite foreseeable negative consequences. On the other hand, nowhere in the world are people expected to foresee all the consequences of their actions: it is widely accepted that there are consequences they cannot foresee and, therefore, for which he cannot be blamed.

On the other hand, just like professional philosophers, ordinary people also differ in their beliefs about what is foreseeable and what is not, and, more importantly, about how much control one has over one's actions. The later beliefs are often implicit and they constitute an important aspect of personality. In cognitive and clinical psychology, there is a relatively long tradition of research on this aspect of personality. This research was pioneered by Julian Rotter (1966), who coined the term locus of control to refer to the extent to which individuals believe that they can control events affecting them. A personal locus of control is conceptualised as being either internal, meaning that the person believes he or she can control his/her behaviour and effect influence on his/her life, or external, meaning the person believes his/her decisions and life are controlled by environmental factors that he or she cannot influence, or by chance or fate (ibid.). However, Rotter has always stressed $(1975 ; 1990)$ that externality and internality are not either-or categories. Rather they are the two poles of a continuum, with the loci of control of real people differing in how close they fall to one or the other of them. Rotter (1966) has also created the first instrument to measure the internality/externality of the locus of control in an individual. This instrument represents a questionnaire consisting of 23 pairs of statements, with the individual choosing one of the statements in each pair. Other instruments were developed later, including the so-called ICI (Internal Control Index; see Duttweiler 1984), which is the most widely used instrument today. These instruments have been used to study differences in the locus of control between individuals and groups. One result of these studies, which is particularly relevant to our topic, has been the demonstration of differences in the locus of control that exist between representatives of different cultures (Berry et al. 2011). Thus several studies have demonstrated that white Americans on average have a more internal locus of control then Afro-Americans and several groups of Native Americans. Differences in the average locus of control have also been reported to exist between Americans and Mexicans (Dyal 1984). Therefore, culture is definitely an important factor influencing a person's locus of control.

Locus of control studies were quite popular in the 1970s and in the first half of the 1980s, but have almost stopped since the early 1990s. They have been replaced by stud- 
ies of the so-called attribution or explanatory style. This concept came from the socalled learned helplessness theory of Martin Seligman (Peterson et al. 1993). Being itself a development of the locus of control theory, the learned helplessness theory focuses not on the extent to which a person believes he or she can control any kind of event, but rather on the extent he or she believes he can control events with a positive affect in comparison to those with a negative affect (Peterson and Seligman 1985; Robins and Hayes 1995). The reason for this switch of focus was the discovery made by Seligman in the middle of the 1970s that, in most people, beliefs about the extent of control exercised over positive and over negative events differ (Seligman 1978; Peterson and Seligman 1985). Thus the majority of people believe that events that affect them positively occur more often due to their own behaviour and personality traits (i.e. for internal reasons). In contrast, negative events are more often attributed to external reasons beyond the actor's control. This difference in attribution came to be known as "self-serving attributive bias" (Miller 1978; Miller and Ross 1975). Just as with the locus of control, this bias has been shown to differ in size between people and groups giving rise to differences in their so-called attribution (or explanatory) styles (Peterson et al. 1995). Thus, there are people who do not have this bias (or have zero bias, as theorists would put it), which means they believe that their ability to control positive and negative events occurring to them is equal. Such people have been termed "attribution realists" or people with "realistic attribution styles" (Robins and Hayes 1995). There are also people who have negative self-serving bias, which means that they believe that positive events more often occur to them due to chance, while negative events are more likely to be a result of their own actions and personality traits. These people are termed "attribution pessimists" (ibid.). Most people have the self-serving attribution bias to a certain extent: they are attribution optimists to different degrees. It should be added that in the most developed form of the learned helplessness theory, the attribution style is based not on the single dimension of internality/externality of control, but on three dimensions (Buchanan and Seligman 1995).

Apart from the internality/externality dimension, there are stability and globality dimensions. Stability refers to the degree a person believes the same events, weather positive or negative, would happen again for the same reasons. Globality refers to the range of events that, as the person believes, can be caused by the same internal or external factor (Peterson et al. 1993; Bentall 2004). The so-called ASQ (Attribution Style Questionnaire; see Peterson et al. 1982), the main instrument psychologists use to assess personal attribution style, measures personal scores on all these three dimensions separately for positive and negative events. Then the mean scores for the three dimensions are summed separately for positive and negative events and the combined score for negative events is subtracted from that for positive events. The size of the self-serving attribution bias obtained in this way has been found to be a good predictor of a range of important medical and social phenomena including the probability of clinical and sub-clinical depression (Peterson and Seligman 1985; Ruehlman et al. 1985; Robins 1988; Robins and Hayes 1995), the probability of cardiovascular disease (Peterson 1995), and, which is important, alcohol consumption (Dowd et al. 1986; Finn and Pihl 1987) and suicide (Peterson 1995). The attribution style, which also varies not only between people but also between cultural groups (Oettingen 1995), has been found to be a much better predictor of these disasters than the locus of control. Hence many modern researchers 
believe that the locus of control theory is outdated and rarely invoke the concept when analysing their data.

\section{RESPONSIBILITY AND LOCUS OF CONTROL AMONG TAZ NENETS}

In 2010, the author of this paper performed comparative research on attribution style among Russian, Nenets and Komi teenagers living in the town of Tazovsky, YamalNenets Autonomous Okrug, and in the city of Syktyvkar, Komi Republic. In that study, the Attribution Style Questionnaire was used to assess the attribution styles of the three groups of children aged between 14 and 15: a group of non-indigenous, Russian-speaking and mainly Russian by identity children who attend the Tazovsky secondary school; a group of Nenets children who attend the Tazovsky boarding school for children from nomadic families; and a group of Komi children who live in two orphanages and one boarding school in the city of Syktyvkar. The details and the results of the study have been published in Russian (Istomin 2011) as well as in English (Istomin 2012). It would be enough to say here that Nenets children have been found to possess a significantly flatter attribution style (their mean self-serving bias was significantly lower) then both Russian and Komi children (Figure 1). This difference could not be explained by factors relating to the physical environment since these factors were similar for Russian and Nenets children. This difference could not be explained by factors relating to the immediate social situation (for example living in a boarding school without parents, living in a new and strange cultural milieu, having a low social status) either. Indeed, Komi children were in a rather similar immediate social situation as the Nenets children, if not worse, since some of them were orphans - although essentially their attribution style did not differ from that of Russian children from Tazovsky. Therefore, cultural reasons for the attribution style differences had to be suspected. On the other hand, the flat attribution style is known to be associated with increased risks of alcoholism and suicide, which could explain the higher rate of these social disasters among the Nenets.

However the comparative data collected in that study showed yet another difference between the Nenets children on one hand and Russian and Komi children on the other. This difference was not discussed in the publications, but can easily be seen in the same Figure 1 showing the combined scores - internality+stability+globality - of each of the three groups separately for positive and for negative events. On this graph, the lines connecting the positive events score with the negative events score for each group represent a good way to see the size of the self-serving attribution biases, i.e. the attribution styles of the group. For the three groups, the lines make slopes descending to the right, which shows that the groups have self-serving biases. It is easy to see that the slope of the Nenets is smaller (i.e. their attribution style is flatter) than those of the other two groups, a fact that has been presented in the publication as the main finding of the study. It is also easy to see, however, that the Nenets' line is also situated much lower than the lines of the other two groups, which suggests that Nenets attribute fewer internal, fewer global and fewer stable reasons to all kinds of events that happen to them, irrespective of whether these are positive or negative. This conclusion is further supported by a comparative analysis of the dimensions: on all three dimensions, the mean scores of Nenets were from 1 to 1.5 points lower than those of Komi and Russians. 
From the viewpoint of attribution style theory, these findings are of little consequence because, as this theory suggests, it is only the self-serving bias, for example the difference between attributions made for positive and for negative events, which matters. However, from the viewpoint of the older locus of control theory these findings are completely essential because they obviously suggest that Nenets children have a more external locus of control in comparison to both Komi and Russian children.

The main reason these findings were not properly discussed in previous publications was that it is rather unclear what they can mean in relation to alcohol/suicide studies. Indeed, as mentioned above, the locus of control turned out to be a rather poor predictor of behaviour or any significant personality characteristic. The single exception is reportedly the subjective feeling of self-efficiency: the more internal is one's locus of control, the more one is inclined to believe that he or she can make a difference (Judge et al. 2002). However, as was argued in the previous paragraph of this paper, there should be a direct relationship between the locus of control and the notion of responsibility as

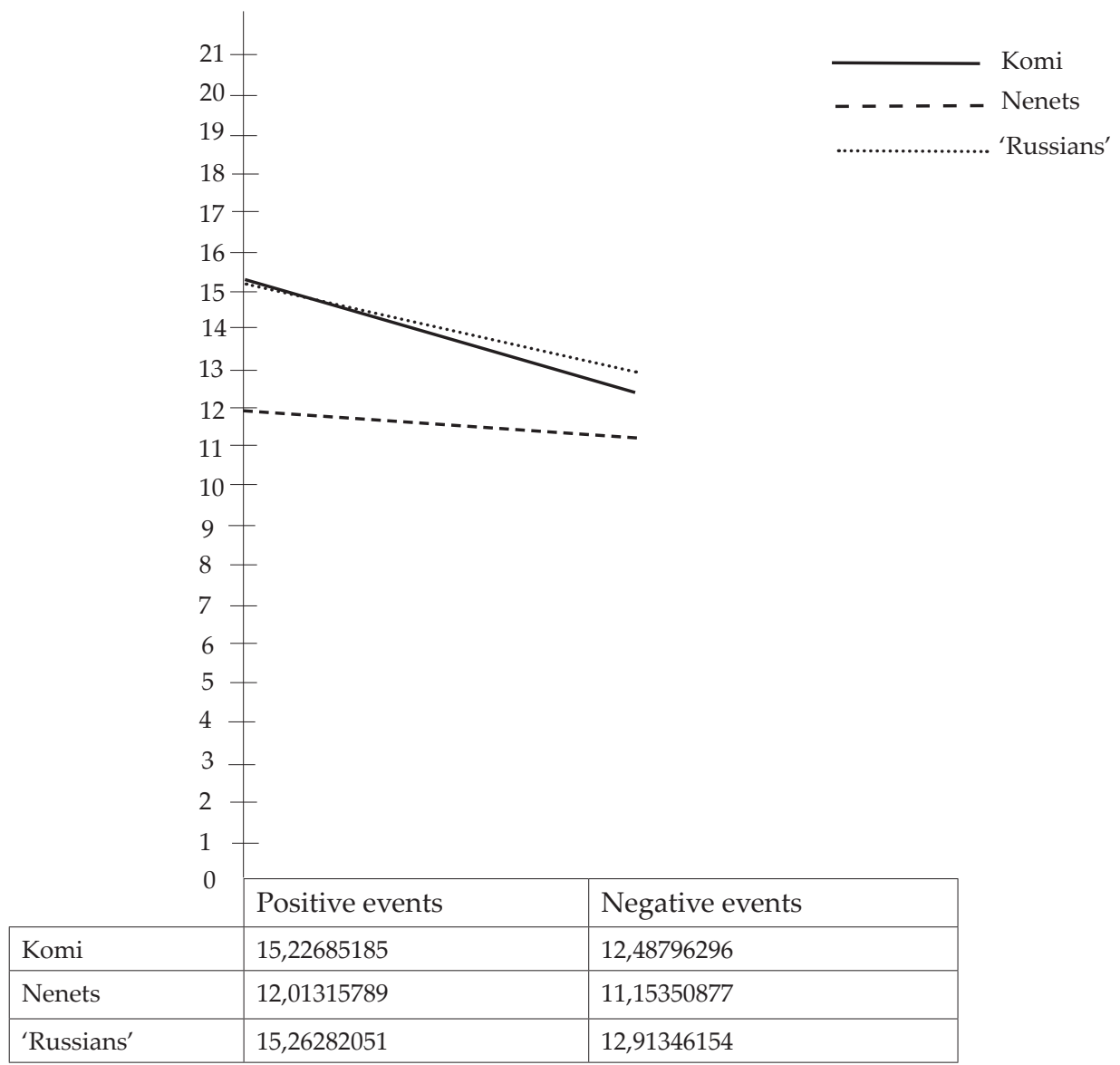

Figure 1. Attributional (explanatory) style of the three groups of children as revealed by the 2010 study (see Istomin 2011; 2012). The graphs represent the contaminant score (internality+stability+globality) for positive and negative events. Note that the graph of Nenets children is situated lower than the graphs of Komi and 'Russian' children. 
a cultural factor. Indeed, in order to hold someone, including oneself, responsible for any act or state of affairs, one should believe that this person has or had a certain degree of control over this act or state of affairs. Indeed, one possibility to explain the flat attribution style among Nenets could have been a reference to a particularly acute sense of responsibility among Nenets. Indeed, it could have been suggested that the Nenets, whose way of life includes everyday struggle alone or in small groups with negative factors of the natural and social environment, should feel more personal responsibility for negative events happening to them or to their families. Hence the small self-serving bias that leads to alcoholism and suicide. This theory is very appealing, although unfortunately the low scores of Nenets in all the three dimensions suggest a very different story. It can be noted, that the Nenets children's scores for negative events are rather similar to those of Russian and Komi, in fact a little bit lower than theirs. Therefore Nenets do not seem to be more inclined to take responsibility for negative events in comparison to the other groups. What makes Nenets really different is that they, it seems, do not praise themselves for the positive events that happen to them, but rather ascribe these events to chance or luck. However, the best way to interpret the data would be to conclude that Nenets take surprisingly little responsibility for both positive and negative events, ascribing them more to chance and situation and believing - as both logic and their low score on stability and globality suggest - that both negative and positive events rarely happen again for the same reasons and that reasons are usually specific and particular, causing few very particular events each. In our comparative study, this fatalistic attitude has just been more visible in the case of positive events due to the persistent tendency of the other groups to give very internal, stable and global reasons to them. But the attitude itself is fairly general.

Indeed, it seems that this fatalistic attitude and the refusal to take or ascribe responsibility can, in fact, be observed among Nenets even directly, without any help of specific quantitative questionnaires. It could be sensed particularly strongly in Nenets informants when the author discussed the topics of alcoholism and suicide with them. The tendency to attribute the causes to alcohol-related events externally is so strong in fact, that it can be detected even on the level of language. Thus, when speaking Russian, Nenets clearly avoid the very famous and colourful Russian expression uyti $v$ zapoy ('to go into binge drinking'). Instead, they prefer passive constructions, among which the most popular is s nim sluchilsya zapoy ('the binge drinking episode happened to him') as well as a very strange expression mne vypilos' (literally 'it drunk to me'), which is profoundly ungrammatical even for Russian. When speaking about suicide, relying completely on the passive voice is difficult because this would not describe the essence of the event adequately. However, even in this case the Nenets have found a way. For Nenets, the usual way to describe a case of suicide in Russian would be yego pereklinilo $i$ on strel'nul sebya. It is very difficult to translate this phrase adequately into English, particularly because, as the author suspects, the Nenets themselves would not be able to explain what the word pereklinilo would mean here. I suspect, that the sole function of this verb is to designate that in the following clause, for example the shot himself down', the actor did not have control over his actions and, therefore, cannot be blamed. In Nenets, the difference between active and passive voices, especially when one refers to the third person, is not quite clear, which, of course, makes the denial of control easier and less visible. 
The denial of control becomes even more obvious when we switch from the way of speaking to the actual things spoken. It should be mentioned first of all that the concepts of good and bad lack, which, as often happens in cultures worldwide, are closely related to the concepts of sacral purity/impurity (see Douglas 1968), play very important roles in the everyday life of the Nenets (Khomich 1995; Kharyuchi 2001). Thus diseases, loss of reindeer, bad lack in fishing and hunting as well as most other negative events are believed to happen to a person because of an accumulation of $s a^{\prime} m e j$, sacral impurity, which, according to some researchers represent the central concept of Nenets culture determining the everyday life of the people (Lyarskaya 2005: 324; see also Lyarskaya 1999). The sa'mej can be accumulated by breaching social norms and taboos, showing disrespect of any sort towards the dead, misbehaving in sacred sites, being near a halmer (surface tomb of a dead person) during the night or after midday, having any kind of sexual intercourse, and by touching sa'mej substances, most notably menstrual blood and the flesh of a dead human, as well as anything that was in contact with these substances (for example the clothes a women wears during menstruation, women's sledge, the clothes of a dead person, his or her sledge, hides that person was laying on, etc.). Although both people and material items can be cleansed of $s a^{\prime} m e j$ by the means of special rituals, these rituals usually involve valuable and difficult-to-obtain substances (for example beaver hair and/or testicles) as well as taking time; therefore, they cannot be performed too often. Therefore, some accumulation of $s a^{\prime} m e j$ is in practice unavoidable. Nenets seem to believe that the more $s a^{\prime} m e j$ one accumulates, the less effective become one's attempts to avoid negative events and create positive events in one's life. Finally, with a certain accumulation of the $s a^{\prime} m e j$, negative events start to happen automatically, irrespective of what one does to prevent them. On the other hand, a high degree of purity ensures positive events and good luck, which come by themselves, without much effort to attract them.

In the light of this description, the attitude of the Nenets towards suicide and alcoholism seems to be quite logical. Thus, Nenets prefer not to discuss the topic of suicide at all, which is rather understandable taking into account that death and all dead things are $s a^{\prime} m e j$. However, the refusal to discuss suicide goes even further then a simple aversion to the topic of death. Thus Nenets informants uniformly refused to consider the reasons for a person's suicide. Unfortunately, like probably any anthropologist who has worked among native northerners, the author has quite a history of being informed about people he knows committing suicide. On each occasion, his first reaction to the information was "Oh my god, why?", which is, probably, quite natural for any nonnative. However, in every single case the reply the Nenets gave to this question was the same: Pereklinilo naverno, and they always tried to demonstrate that any further discussion of the topic would be out of place as far as they are concerned. A proposal that the suicide could be a reaction to someone's behaviour or attitude and, therefore, that someone could be responsible for it was usually rejected almost with disgust.

Understandably, the topic of alcoholism was much easier to discuss and, therefore, the examples of fatalistic attitudes towards it are more numerous. "The weather is good, he will be back by the day after tomorrow if a binge drinking episode does not happen to him" (Pogoda khoroshaya, poslezavatra vernetsya, yesli yemu ne zap'yetsya) - this is what reindeer herders would often say about someone who has just left to a village or gone to a neighbouring brigade. "I was going to be back in one day, but suddenly a binge drink- 
ing episode happened to me" - that is how a herder would often start a story - usually a sad one - that has happened to him in a village. All these phrases and statements have a distinct scent of helplessness, the implication that a person lacks any control over his drinking behaviour, that drinking just happens to him. During the fieldwork I encountered only very few instances when someone was held responsible for his or her drinking behaviour, although even these instances usually only supported the rule. Thus, once the author was told a story about a herder who gave up drinking after being 'coded' (treated for alcoholism by the means of hypnosis) in the village. After becoming a non-drinker, this herder became very greedy for money and started several business projects. One of them consisted in bringing vodka to the tundra and selling it to herders for inflated prices. However, a little bit later the herder was suddenly 'de-coded' and had a particularly long and heavy binge-drinking episode, which cost him a large part of his property. Thus during this episode he slaughtered most of his reindeer to give meat to his new friends - Russian businessmen - whom he asked to bring him vodka in return. The narrator said, that this drinking episode was just a punishment to the herder for his previous greed and particularly for his selling vodka in the tundra to other herders, which clearly was sa'mej. The herder brought this misfortune upon himself and, therefore, was responsible for it. This was a punishment the herder deserved but did not want - a fate he could not avoid.

\section{CONCLUSIONS: LOCUS OF CONTROL AND THE ATTRIBUTION STYLE}

It would be appropriate to ask why this kind of strong fatalism - or the external locus of control - is present among Nenets. This question has not yet been addressed empirically and any attempt to give a reply to it would involve a certain degree of speculation. There can be little doubt that the external locus of control is related to the system of beliefs about luck and $s a^{\prime} m e j$ described briefly in the previous paragraph. However, the exact character of this relationship is not clear: although it is possible that the beliefs about luck and $s a^{\prime} m e j$ contribute to the formation of the external locus of control, it is also possible that it is the external locus of control that gives rise to these beliefs. What is more likely, however, is that this relationship is mutual as is the case with many other cognitive phenomena: the beliefs in $s a^{\prime} m e j$ contribute to the externalisation of the locus of control, while the more external locus of control contribute to the deepening and spread of $s a^{\prime} m e j$ beliefs. In any case, however, since cultural phenomena cannot cause themselves, the specific beliefs can only be the proximate cause of the external locus of control, not the ultimate cause.

It can be cautiously supposed that the highly external locus of control can be related to the flat attribution style that has been observed among Nenets (Istomin 2011; 2012). Indeed, the flat attribution style of Nenets actually means that the negative events cause more stress to them, which can easily lead them to hypodepression, and then to subclinical and clinical depression, and cause higher risk of suicide and alcoholism. For anyone who has an attribution style of this kind, it can indeed be a good idea to keep the locus of control as external as possible. A tendency to attribute external, unstable and local reasons to both positive and negative events decrease the psychological effects of 
all events and, therefore, mediates the impact of the small difference between positive and negative attributions. Therefore, the external locus of control can be a psychological mechanism to compensate for the flat attribution style. The other possibility can be that the flat attribution style as observed in the study of 2010 (see Istomin 2011; 2012) can be a consequence of, rather than a reason for, the external locus of control. Indeed, given the general difference in the locus of control, the difference in the self-serving attribution bias between the groups can be a measurement artefact. To make it clearer, let's take an analogue: the difference in size between, let's say, an ant and a mouse is a dozen centimetres. The difference in size between a men and an elephant, on the other hand, amounts to several metres. Does this mean that the difference in size between a man and an elephant is bigger than that between an ant and a mouse? Yes if we are speaking about absolute numbers. No if we are speaking about relative sizes. In fact, the difference between the mouse and the ant is relatively larger. The same can be true here: although the self-serving biases of Komi and Russians are bigger in absolute numbers, the self-serving bias of the Nenets can be just as big if their general tendency to ascribe reasons to external factors is taken in consideration. Seligman, the author of the attribution style theory would decline this idea - he seems to believe that this is an absolute rather than a relative difference between the positive and the negative attributions that predicts the behavioural and psychological effects. However in fact there is nothing in his theory that would justify such a belief. Just the contrary in fact, it seems that the general design of the theory would suggest exactly the opposite: it should be the internality, stability and globality of positive attributions relative to the externality, stability and globality of the negative attribution that would predict learned helplessness. The smaller is the latter, the smaller the former can be and the smaller should be the difference between the two in order to lead to the same psychological effects.

Whatever the reasons are, the external locus of control is probably responsible for a number of phenomena in Nenets society - some of them are negative and others are positive. Thus it is intuitively obvious that the denial of personal responsibility greatly decreases the effectiveness of both personal and social moral control and motivation. Indeed, it hardly makes any sense to explain how alcoholism is morally disgusting and devastating for heath to someone who does not in fact believe that it is up to him or her to choose between drinking and not drinking. Of course, a society that believes alcoholism and suicides just happen to people would hardly press on its members to avoid these disasters. Finally, the low perceived self-effectiveness that is associated with external locus of control is generally not a good thing in modern society. On the other hand, there are positive aspects as well. The certain resistance to stress has already been mentioned. The other thing is sensitivity to external influences on health. People who believe that things just happen to them can also be easily assured that they can cease to happen. It can be supposed that the good effects of the anti-alcohol coding in the case of the Nenets can be somehow related to this fact. 


\section{REFERENCES}

Abryutina, Larisa I. 1999. Narody Severa Rossii: pravo na zdorov'ye. Moskva. [Абрютина, Лариса И. 1999. Народы Севера России: право на здоровъе. Москва.]

Arctic Human Development Report. 2004. Publication of the Sustainable Development Programme of the Arctic Council. Akureyri: Sefansson Arctic Institute.

Bentall, Richard P. 2004. Madness Explained: Psychosis and Human Nature. London; New York, NY: Penguin.

Berry, John W.; Ype H. Poortinga, Seger M. Breugelmans, Athanasios Chasiotis and David L. Sam. 2011. Cross-Cultural Psychology: Research and Applications. Cambridge: Cambridge University Press. DOI: https://doi.org/10.1017/CBO9780511974274.

Bogoyavlenskiy, Dmitriy D. 2008. Narody severa Rossii: demograficheskiy profil' na rubezhe vekov. - Vliyaniye global'nykh klimaticheskikh izmeneniy na zdorov'ye naseleniya rossiyskoy Arktiki, edited by B. A. Revich. Moskva: Publikatsiya rossiyskogo otdeleniya Organizatsii Ob"yedinennykh Natsiy, 14-17. [Богоявленский, Дмитрий Д. 2008. Народы севера России: демографический профиль на рубеже веков. - Влияние глобальных климатических изменений на здоровье населения российской Арктики, отв. ред. Б. А. Ревич. Москва: Публикация российского отделения Организации Объединенных Наций, 14-17.]

Bogoyavlenskiy, Dmitriy D. and Aleksandr I. Pika. 1991. Nasil'stvennaya smertnost' u narodov Severa (na primere Kamchatki i Chukotki). - Geografiya i khozyaystvo 4. Rayony prozhivaniya malochislennykh narodov Severa, edited by A. I. Chistobalev. Leningrad: GO SSSR, 162-182. [Богоявленский, Дмитрий Д. и Александр И. Пика. 1991. Насидьственная смертность у народов Севера (на примере Камчатки и Чукотки). - География и хозяйство 4. Районь проживания малочисленных народов Севера, отв. ред. А. И. Чистобаев. Ленинград: ГО CCCP, 162-182.]

Brown, Leslie, ed. 2009. Aristotle: Nicomachean Ethics. Oxford: Oxford University Press.

Buchanan, Gregory McClellan and Martin E. P. Seligman, eds. 1995. Explanatory Style. Hillsdale: L. Erlbaum.

Douglas, Mary. 1968. Purity and Danger: An Analysis of Concept of Pollution and Taboo. London: Routledge \& Kegan Paul.

Dowd, E. Thomas; Gary W. Lawson and Richard Petosa. 1986. Attributional Styles of Alcoholics. - The International Journal of the Addictions 21 (4-5): 589-593. DOI: https://doi. org/10.3109/10826088609083543.

Duttweiler, P. C. 1984. The Internal Control Index: A Newly Developed Measure of Locus of Control. - Educational and Psychological Measurement 44 (2): 209-221. DOI: https://doi. org/10.1177/0013164484442004.

Dyal, James A. 1984. Cross-Cultural Research with the Locus of Control Construct. - Research with the Locus of Control Construct 3. Extensions and Limitations, edited by H. M. Lefcourt. London: Academic Press, 209-306.

Eshleman, Andrew. 2014. Moral Responsibility. - The Stanford Encyclopedia of Philosophy, edited by Edward N. Zalta. http://plato.stanford.edu/archives/sum2014/entries/moral-responsibility/ (accessed November 10, 2016).

Finn, Peter R. and R. O. Pihl. 1987. Men at High Risk for Alcoholism: The Effect of Alcohol on Cardiovascular Response to Unavoidable Shock. - Journal of Abnormal Psychology 96 (3): 230-236. DOI: https://doi.org/10.1037/0021-843X.96.3.230.

Istomin, Kirill V. 2011. "Atributivnyy stil"' i problema p'yanstva I samoubiystv sredi malochislennykh narodov severa i Sibiri. - Etnograficheskoye Obozreniye 2: 89-106. [Истомин, Кирилл В. 2011. «Атрибутивный стиль» и проблема пьянства и самоубийств среди малочисленных народов севера и Сибири. - Этнографическое Обозрение 2: 89-106.] 
Istomin, Kirill. 2012. Once Again on the Problem of Alcoholism and Suicide Among the Indigenous Peoples of the Russian North: Can Attribution Style Be a Factor? - Sibirica 11 (3): 1-19.

Judge, Timothy A.; Amir Erez, Joyce E. Bono and Carl J. Thoresen. 2002. Are Measures of SelfEsteem, Neuroticism, Locus of Control, and Generalized Self-Efficacy Indicators of a Common Core Construct? - Journal of Personality and Social Psychology 83 (3): 693-710. DOI: https:// doi.org/10.1037/0022-3514.83.3.693.

Kharyuchi, Galina P. 2001. Traditsii i innovatsii v kul'ture nenetskogo etnosa (vtoraya polovina XX veka). Tomsk: Izdatel'stvo tomskogo universiteta. [Харючи, Гадина П. 2001. Традиции и инновации в культуре ненецкого этноса (вторая половина XX века). Томск: Издательство томского университета.]

Khomich, Lyudmila V. 1995. Nentsy. Ocherki traditsionnoy kul'tury. Sankt-Peterburg: Russkiy dvor. [Хомич, Аюдмила В. 1995. Ненцьь. Очерки традиционной культуры. Санкт-Петербург: Русский двор.]

Klokov, Konstantin B. 1996. Kochevoye olenevodcheskoye naseleniye: otsenka vozmozhnostey etnosotsial'noy adaptatsii i razvitiya. Sankt-Peterburg: SPbU. [Клоков, Константин Б. 1996. Кочевое оленеводческое население: оценка возможностей этносоциальной адаптациии и развития. Санкт-Петербург: СПбУ.]

Kozlov, A. I.; G. G. Vershubskaya, M. A. Kozlova and L. Shmit. 2002. Modernizatsionnyy stress u korennogo naseleniya severa Zapadnoy Sibiri. Moskva: IEA RAN. [Козлов, А. И.; Г. Г. Вершубская, М. А. Коздова и А. Шмит. 2002. Модернизационный стресс у коренного населения севера Западной Сибири. Москва: ИЭА РАН.]

Lyarskaya, Yelena V. 1999. “Kompleks zhenskikh zapretov i pravil u nentsev Yamala. - Problemy sotsial'nogo i gumanitarnogo znaniya. Sbornik nauchnykh rabot 1. Sankt-Peterburg: Yevropeyckiy universitet, 272-292. [Лярская, Елена В. 1999. Комплекс женских запретов и правил у ненцев Ямала. - Проблемы социального и гуманитарного знания. Сборник научных работ 1. Санкт-Петербург: Европейский университет, 272-292.]

Lyarskaya, Elena. 2005. Zhenskiye zaprety i kompleks predstavleniy o nechistote u nentsev. Antropologicheskiy Forum 2: 317-326. [Лярская, Елена В. 2005. Женские запреты и комплекс представлений о нечистоте у ненцев. - Антропологический Форум 2: 317-326.]

Miller, Dale T. 1978. What Constitutes a Self-Serving Attributional Bias? A Reply to Bradley. Journal of Personality and Social Psychology 36 (11): 1221-1223. DOI: https://doi.org/10.1037/00223514.36.11.1221.

Miller, Dale T. and Michael Ross. 1975. Self-Serving Biases in the Attribution of Causality: Fact or Fiction? - Psychological Bulletin 82 (2): 213-225. DOI: https://doi.org/10.1037/h0076486.

Nichols, Shaun and Joshua Knobe. 2007. Moral Responsibility and Determinism: The Cognitive Science of Folk Intuitions. - Nous 41 (4): 663-685. DOI: https://doi.org/10.1111/j.14680068.2007.00666.x.

Oettingen, Gabriele. 1995. Explanatory Style in the Context of Culture. - Explanatory Style, edited by Gregory McClellan Buchanan and Martin E. P. Seligman. London: Routledge, 209-224.

Peterson, Christopher; Amy Semmel, Carl von Baeyer, Lyn Y. Abramson, Gerald D. Metalsky and Martin E. P. Seligman. 1982. The Attribution Style Questionnaire. - Cognitive Therapy and Research 6 (3): 287-300. DOI: https://doi.org/10.1007/BF01173577.

Peterson, Christopher and Martin E. P. Seligman. 1985. The Learned Helplessness Model of Depression: Current Status of Theory and Research. - Handbook of Depression: Treatment, Assessment, and Research, edited by Edward E. Beckham and William R. Leber. Homewood, ILL: Dorsey Press, 914-939.

Peterson, Christopher; Steven F. Maier and Martin E. P. Seligman. 1993. Learned Helplessness: A Theory for the Age of Personal Control. New York, NY: Oxford University Press.

Peterson, Christopher. 1995. Explanatory Style and Health. - Explanatory Style, edited by Gregory McClellan Buchanan and Martin E. P. Seligman. London: Routledge, 233-246. 
Peterson, Christopher; Gregory McClellan Buchanan and Martin E. P. Seligman. 1995. Explanatory Style: History and Evolution of the Field. - Explanatory Style, edited by Gregory McClellan Buchanan and Martin E. P. Seligman. London: Routledge, 1-20.

Pika, Alexandr I. 1987. Demograficheskaya politika v rayonakh prozhivaniya narodov Severa: problemy i perspektivy. - Regional'nye problemy sotsial'no-demograficheskogo razvitiya, edited by В. B. Prokhorov. Moskva: Nauka, 43-55. [Пика, Александр И. 1987. Демографическая политика в районах проживания народов Севера: проблемы и перспективы. - Региональные проблемы социально-демографического развития, отв. ред. Б. Б. Прохоров. Москва: Наука, 43-55.]

Pivneva, Yelena A. 2005. Etnodemograficheskiye aspekty problemy alkogolizma u malochislennykh narodov severa. - V poiskakh sebya: Narody Severa i Sibiri v postsovetskikh transformatsiyakh, edited by Y. A. Pivneva and D. A. Funk. Moskva: Nauka, 65-84. [Пивнева, Елена A. 2005. Этнодемографические аспекты проблемы алкогодизма у малочисленных народов севера. - В поисках себя: Народы Севера и Сибири в постсоветских трансформациях, отв. ред. Е. А. Пивнева и Д. А. Функ. Москва: Наука, 65-84.]

Robins, Clive J. 1988. Attributions and Depression: Why Is the Literature So Inconsistent? Journal of Personality and Social Psychology 54 (5): 880-889. DOI: https://doi.org/10.1037/00223514.54.5.880.

Robins, Clive J. and Adele M. Hayes. 1995. The Role of Causal Attributions in the Prediction of Depression. - Explanatory Style, edited by Gregory McClellan Buchanan and Martin E. P. Seligman. London: Routledge, 71-98.

Rotter, Julian B. 1966. Generalized Expectancies for Internal Versus External Control of Reinforcement. - Psychological Monographs: General and Applied 80 (1): 1-28. DOI: https://doi.org/10.1037/ h0092976.

Rotter, Julian B. 1975. Some Problems and Misconceptions Related to the Construct of Internal Versus External Control of Reinforcement. - Journal of Consulting and Clinical Psychology 43 (1): 56-67. DOI: https://doi.org/10.1037/h0076301.

Rotter, Julian B. 1990. Internal Versus External Control of Reinforcement: A Case History of a Variable. - American Psyhologist 45 (4): 489-493. DOI: https://doi.org/10.1037/0003-066X.45.4.489.

Ruehlman, Linda S.; Stephen G. West and Robert J. Pasahow. 1985. Depression and Evaluative Schemata. - Journal of Personality 53 (1): 46-92. DOI: https://doi.org/10.1111/j.1467-6494.1985. tb00888.x.

Seligman, Martin E. P. 1978. Comment and Integration. - Journal of Abnormal Psychology 87 (1): 165-179. DOI: https://doi.org/10.1037/0021-843X.87.1.165.

Spillane, Nichea S. and Gregory T. Smith. 2007. A Theory of Reservation-Dwelling American Indian Alcohol Use Risk. - Psychological Bulletin 133 (3): 395-418. DOI: https://doi. org/10.1037/0033-2909.133.3.395.

Vitebsky, Piers and Sally Wolfe. 2001. The Separation of the Sexes Among Siberian Reindeer Herders. - Sacred Custodians of the Earth? Women, Spirituality and Environment, edited by Alaine Low and Soraya Tremayne. New York, NY: Berghan, 81-94.

Woolfolk, Robert L.; John M. Doris and John M. Darley. 2008. Identification, Situational Constraint, and Social Cognition: Studies in the Attribution of Moral Responsibility. - Experimental Philosophy, edited by Joshua Knobe and Shaun Nichols. Oxford: Oxford University Press, 61-80. 